\title{
Possibilities of utilizing the solid by-products of biodiesel production - a review
}

\author{
Elżbieta Gąsiorek, Marta Wilk \\ Wroclaw University of Economics, Department of Agricultural and Food Bioutilization, ul. Komandorska 118/120, \\ 53-345 Wroctaw, Poland, e-mail: elzbieta.gasiorek@ue.wroc.pl, marta.wilk@ue.wroc.pl
}

\begin{abstract}
As a consequence of the intended rise in the volume of the biodiesel produced by the member states of the European Union, predominantly from rapeseeds and sunflower seeds, the quantity of the by-products being generated, e.g. glycerol, rapeseed/sunflower seed straw and rapeseed/sunflower seed meal, will increase dramatically. It is therefore recommendable to find effective methods for their processing or utilization in order to reduce the costs of biodiesel production without polluting the environment by excessive wastes. As the utilization of glycerol has often been addressed in the literature ${ }^{1}$, the aim of our study is to describe the potentiality for utilizing the solid by-products of biodiesel production, namely rapeseed/sunflower straw and rapeseed/ sunflower seed meal.
\end{abstract}

Keywords: renewable energy, biodiesel, rapeseed straw, rapeseed meal, sunflower seed meal, white biotechnology.

\section{INTRODUCTION}

The world energy demand continues to increase. In order to reduce dependency on fossil fuels and decrease the environmental pollution, it is necessary to search for alternative fuels. Biofuels - solid, liquid, or gaseous - are currently the only direct substitute for fossil fuels available on a significant scale ${ }^{2}$. In the EU, according to the biofuels directive (2003/30/EC of 8 May 2003) a $2 \%$ market share was targeted for biofuels in 2005 and 5,75 share in $2010^{3}$. In the transportation sector, the directive 2009/28/EC of 23 April 2009 set the target for biofuels usage of $10 \%$ by the end of 2020 (at present it is 4,7\%).

Biofuels include e.g. biodiesel, bioethanol, biomethanol, biogas, biohydrogen, bio-ETBE and bio-MTBE ${ }^{4}$. Although the world's biofuel market has been dominated by bioethanol, in the European Union preference is still being given to biodiesel. Currently, $80 \%$ of EU biofuels consumption in the transport sector is biodiesel and $20 \%$ bioethanol $^{3}$. Biodiesel defined as the fatty acid alkyl monoesters derived from renevable feedstocks, such as vegetable oils, animal fats or recycled fats and oils of diesel quality ${ }^{3,5}$ has became more attractive recently because of their environmental benefits and the fact that it is made from renewable resources.

The chemical composition of biodiesel is dependent upon the feedstock from which it is produced, as vegetable oils and animal fats of differing origin have dissimilar fatty acid composition. The fatty ester composition of biodiesel is identical to that of the parent oil or fat from which it was produced ${ }^{5,6}$. Feedstocks for biodiesel production vary with the location according to the climate and availability; rapeseed and sunflower oils are principally used in Europe, palm oil predominantly in tropical countries, and soybean oil and animal fats are most common in the $\mathrm{USA}^{7}$. In Poland, the annual volume of rapeseed production approaches one million tons. There are, however, potentialities for increasing this quantity to 2.5 million tons per year, of which more than 1.75 million tons could be used for technological purposes, but primarily for the production of methyl esters ${ }^{8}$.

The production of one ton of biodiesel requires approximately one ton of rapeseed oil, which is an equiva- lent of 3.3 tons of rape as a starting raw material. The problem is how to utilize all by-products and wastes obtained, assuming that one ton of the rape seeds processed yields approximately $650 \mathrm{~kg}$ of rapeseed meal. It is predicted that the use of another raw material for biodiesel production, i.e. sunflower oil, will rise from 59 to 81 thousand tons, which will increase the quantity of the sunflower seed meal available on the market to approx. 200 thousand tons. A rise will also be observed in the quantity of straw, a waste obtained at the first stage of production, i.e. at rapeseed or sunflower seed harvest.

The volume of the generated solid wastes will increase with the ever growing biodiesel oil production. That is why the problem of finding a cost-effective, and simultaneously an environmentally sustainable method for the utilization of those wastes has taken on a sense of particular significance.

The aim of this study is to review the recent trends in the utilization of straw and rapeseed/sunflower seed meals, the by-products of biodiesel manufacture from rapeseed oil and sunflower oil.

\section{STRAW UTILIZATION}

Rape/sunflower straw is a by-product of rape/sunflower cultivation aimed at obtaining rape/sunflower oils for the needs of oil industry and biodiesel production.

\section{Straw used in agriculture and food processing}

Straw serves various useful functions. Produced from oilseed plant, straw can be used as bedding for farm animals or as an additive in fodder. As a source of fibre, it is inferior to crops such as flax, hemp or linseed, but superior to cereal straw. Straw may also be utilized as a compost component or as an additive, improving the humus content of the soil ${ }^{9}$. Stems, petals and leaves of the sunflower contain many valuable components, utilizable as raw materials for the production of foods, fodders, or cosmetics.

\section{Combustion of rapeseed straw}

As the composition of rapeseed straw is similar to that of wood and the force required for briquette disintegra- 
tion is very low ${ }^{\mathbf{1 0}}$, one of the possible ways of utilizing this waste material includes combustion, and a big number of farms use straw for heating the living quarters ${ }^{\mathbf{1 1}}$. There are, however, some major disadvantages in this method: the low calorific value $(15 \mathrm{MJ} / \mathrm{kg})$ and the high moisture content $(30-40 \%)$ of rapeseed straw. In addition, straw is an expensive fuel, and 15 years of experience have shown that straw is rather problematic as a fuel for heatand power generation'. Metals in ash (in combination with other fuel elements such as silica and sulphur, and facilitated by the presence of chlorine) are responsible for many undesirable reactions in combustion furnaces and power boilers ${ }^{\mathbf{1 0}}$. Co-firing of coal and straw in the existing power plant boilers is proposed as it offers advantages of separate straw combustion ${ }^{11}$. Also the storage of the straw, when use is made of barns with solid roofs, is problematic. Although there is an alternative method which allows straw bales to be stored in large, open, plastic or tarpaulin covered stacks in the field with low storage costs, this is concomitant with feedstock losses ${ }^{11}$.

\section{Rapeseed straw as a composite with thermoplastic poly- mers}

It has been found that the wooden parts of rape stems can be a valuable source of lignocellulosic materials which can be used for the manufacture of composites with thermoplastic polymers, such as polypropylene or polyethylene. Polyolefin composites reinforced with natural fibres, e.g. rapeseed straw are used in furniture, building and automotive industries ${ }^{12}$. The availability of the inexhaustible and renewable sources, low costs and the recycling opportunity make natural materials very attractive ${ }^{13}$. However, there are some limitations on the wide application of this materials such as the lack of repeatability of chemical composition, the capability of absorbing moisture, the biological degradability and low resistance to high temperature ${ }^{14}$.

\section{Straw as a cellulosic material for biotechnological uses}

As a lignocellulosic material, rapeseed/sunflower straw contains cellulose and hemicelluloses that are bound together by lignin. Both cellulose and hemicelluloses are polymers built of long chains of sugar monomers, which after pretreatment and hydrolysis can be converted to sugars ${ }^{15}$. While the lignin content represents a potentially large energy source, current techniques involving hydrolysis/enzymatic systems cannot convert the lignin to syngas ${ }^{16}$. Delignification of rapeseed straw under alkaline conditions was found to be inefficient due to a high content of alkali consuming substances. To overcome these difficulties, treatments prior to delignification such as storage on the fields and prehydrolysis have been proposed ${ }^{17}$.

An interesting issue addressed in the literature is biorefining based on the separation of the main botanical parts of the crop into different fractions, which can then be used as feedstock for various conventional and new industrial applications $\mathbf{s}^{\mathbf{1 8}}$. Current research on the biodegradation or bioutilization of cellulose wastes covers the areas specified below.

\section{Biotransformation to fuel}

Biofuels are promising substitutes for fossil fuels because they can be produced from biomass which is renew- able $^{15}$. Owing to its high content of carbohydrates (more than $60 \%$ ), rapeseed straw is regarded as an attractive raw material for fuel ethanol production ${ }^{\mathbf{1 5}}{ }^{19}$. Bioethanol as a liquid fuel can readily be integrated into the existing fuel supply systems and directly substitute fossil fuels in the transportation sector ${ }^{20}$. Bioethanol production from lignocellulose requires chemical/physical pretreatment to loosen up the lignocellulosic structure and facilitate enzymatic hydrolysis ${ }^{\mathbf{1 5}, \mathbf{2 1}}$. Biomass pretreatment technology has been widely investigated in recent years and various biological, chemical and physical pretreatment approaches have been proposed to increase the susceptibility of cellulose to enzymatic attack ${ }^{15,19}$. Hydrolysis can be performed enzymatically or with mineral acids. Since the process conditions for enzymatic hydrolysis and ethanol fermentation are relatively similar, ethanol from lignocellulosic materials can be produced by a simultaneous saccharification and fermentation process ${ }^{\mathbf{2 1}, 22}$.

Rapeseed straw is considered as a feedstock for gasification and pyrolysis ${ }^{11}$. The pyrolysis of straw-stalk of rape plants shows the potential of rape plants as an important source of liquid hydrocarbon fuels ${ }^{23}$. Pyrolytic oil is a carbon rich, hydrocarbon mixture bearing oxygen at a considerable ratio and containing ash, sulphur and nitrogen in very small quantities. Rapeseed straw is also a good biomass feedstock for the production of biohydrogen ${ }^{20}$.

\section{Production of organic acids}

Pentoses (mainly xylose) can be used for the synthesis of fumaric acid. To enhance this process, it is advisable to immobilize the mycelium of the species Rhizopus arrizus on appropriate carriers. When use is made of combined saccharification by the cellulases of $T$. reesei and $L$. delbrueckii, the cellulose materials will be efficiently converted to lactic acid ${ }^{24}$.

\section{Biomass production}

Fungal, bacterial and yeast biomass was produced using the submerged cultures method, as well as cultures in a solid-state medium. Use was made of such strains that had the capacity for degrading cellulose and hemicelluloses, and in some instances also lignin. Upon hydrolysis of polysaccharides to monosaccharides and after making up the hydrolysate with nutrients, yeasts of the genus Candida were cultured, which yielded the proteinenriched fodder ${ }^{25}$.

\section{Sweetener production from hemicelluloses}

Using a microbiological method, it is possible to obtain a sweetener from D-xylose. The sweetener obtained via this route is termed xylitol and can be administered to diabetics as a sugar substitute. The yeast species Candida guillermondii has the capacity for a high conversion of xylose to xylitol ${ }^{24}$.

\section{Straw as a biosorbent of heavy metals}

Vegetable wastes can act as biosorbents of heavy metals carried by a wastewater stream. In order to enhance sorption, the lignocellulose substrate is modified using different methods. However, straw is a biodegradable material, so it will release the heavy metals into the soil in the course of the degradation process ${ }^{26}$. 


\section{UTILIZATION OF RAPESEED/SUNFLOWER SEED MEALS}

The rapeseed/sunflower seed meal, is a by-product from crushing, expelling and extracting oil from oilseed rape/ sunflower. It is solid fraction, with a dry mass content of 90 to $92 \%$. The composition of rapeseed meal widely vary based on the quality of the seed, the method of oil extraction, storage parameters, etc. ${ }^{27}$. It is composed of $(\%)$ : protein, 30.5 - 32; crude fat, 12.6 - 18, and crude fibre, $10-13.8^{28,29}$.

The pertinent values for the sunflower seed meal (\%) are: protein, 27.5; crude fat, 15.0, and crude fibre, 25.028. In dehulled sunflower seed meal the protein content is higher $(40 \%)$ and fibre content is lower $(10 \%)^{30}$.

\section{Rapeseed and sunflower seed meals as fodder supplements}

Owing to the high protein and fat content, as well as the well-balanced amino-acid composition, rapeseed and sunflower seed meals are regarded as valuable fodder supplements in stock-breeding, particularly in pig, poultry, ruminant and fish farming ${ }^{28}$. However, the high content of lignin and cellulose, and the glucosinolate content is a major limiting factor in the feeding of young farm animals ${ }^{29}$. Another limiting factor is the low level of threonine and lysine. It is therefore recommended that the proportion of the rapeseed/sunflower seed meal in the fodder for the fattening pig should not exceed $15 \%$. As a consequence of the chemical changes occurring in the fat fraction, the storage life of the rapeseed/sunflower seed meal ranges between two and three months only.

\section{Rapeseed and sunflower seed meals as energy sources}

In the past 10 years, many farms and individual dwellings have switched from hard coal to firewood, wood waste briquettes and pellets ${ }^{31}$. In a pellet form, both meals can be used as combustibles, owing to their high calorific value, which is $26 \mathrm{MJ} / \mathrm{kg}$ and $19 \mathrm{MJ} / \mathrm{kg}$ for rapeseed meal and sunflower seed meal, respectively. They can also be used in composites with products of a higher calorific value, such as coal or heating oil ${ }^{32}$. However, no costeffective, environmentally sustainable technology has been reported so far for the combustion (or co-combustion) of rapeseed meal or sunflower seed meal in order to obtain energy.

The literature contains references to their use for the liquid fuel production by pyrolysis. The calorific value of the fuel amounted to $33.7 \mathrm{MJ} \mathrm{kg}^{-133}$ or $24 \mathrm{MJ} \mathrm{kg}^{-134}$. Using pyrolysis, it is also possible to obtain charcoal from rapeseed plant straw-stalk ${ }^{23}$.

\section{Rapeseed meal as a source of proteins and amino acids}

In the search for new protein products for human consumption, defatted rapeseed meal has been considered as a potential source of food-grade proteins because of its well-balanced amino-acid composition ${ }^{35}$. However, the meal contains many undesired components, especially phenolic compounds, among which phenolic acids and condensed tannins are predominant. The high levels of phenolics may be responsible for the dark colour, bitter taste and astringency of the rapeseed meal. Since phenolic acids and condensed tannins may both form complexes with proteins, it is necessary to break phenolic-protein complexes i.e. through a system that combines a series of chemical treatments with membrane processing ${ }^{36}$, and then to separate the released phenolic compounds from the proteins ${ }^{36,37}$.

\section{Rapeseed as a source of antioxidants}

It has been found that phenolic compounds derived from rapeseed are able to effectively prevent lipid oxidation in rapeseed oil ${ }^{38}$. Therefore, extracts from the byproducts of rapeseed oil processing can be used to stabilize the refined oils with low amounts of endogenous phenols. This concept can be applied to the commercially refined rapeseed oils after the processing to stabilize the oils with antioxidants naturally present in rapeseed. Antioxidants from rapeseed extracts can also be used in various foodstuffs instead of the commercial ones.

\section{Rapeseed/sunflower seed meals as carbon and energy sources in biotechnological processes}

Being rich in protein and fat, with a well-balanced aminoacid composition, rapeseed/sunflower seed meals can be used as both carbon and nitrogen sources in the biosynthesis of valuable metabolites. These have been utilized for the fermentative production of enzymes, antibiotics and mushrooms.

Rapeseed meal has been used as a substrate for xylanase production by Trichoderma reesei. Maximum xylanase activity amounted to $210 \mathrm{IU} / \mathrm{ml}$ and was obtained within 9 to 12 days $^{39}$. Another reported use of rapeseed meal in phytase production during solid state fermentation by Aspergillus niger ${ }^{40}$ and by Aspergillus ficuum NRRL $3135^{41}$.

Sunflower seed meal has been used as a substrate for the production of enzyme $\alpha$-amylase with Bacillus licheniformis ${ }^{42}$ and pharmaceuticals: Cephamycin $\mathrm{C}$ with Streptomyces clavuligerus $^{\mathbf{4 3}}$ and clavulanic acid with S. clavuligerus ${ }^{4}$. When added as a supplement to the production medium with spent rice straw, sunflower seed meal enhanced mushroom production ${ }^{45}$.

In recent years, research has been conducted on the applicability of rapeseed meals in the biosynthesis of organic acids. The rapeseed meal was found to be an effective medium for $A$. niger in the synthesis of oxalic acid by solid state fermentation, and the maximum concentration of the product approached $150 \mathrm{~g} \mathrm{~kg}^{-1} \mathrm{dry}$ weight. The bioprocess was characterized by high chemical selectivity as only oxalic acid was found in the post fermentation media ${ }^{46}$.

\section{CONCLUSIONS}

The rate of biodiesel production continues to increase. Internationale Grains Council indicated that rapeseed oil was the predominant feedstock for the worldwide biodiesel production in 2007 (48\%, 4.6 million metric tons $\left.{ }^{6}\right)$, and it seems that this trend will be continued. It has necessitated the development a thorough search for the costeffective and environmentally sustainable methods for the utilization of the generated by-products, such as rapeseed/ sunflower straw and rapeseed/sunflower seed meal. In addition to the conventional use of those lignocellulosic materials for heat generation or in stock-breeding, there are new recommendable methods of their utilization. The most promising one is the so-called white biotechnology 
which offers potential benefits with regard to economic and environmental protection. Bioprocesses could be useful to biorefinery as an important means to the excessive by-products disposal problem with a potential for revenues from the value-added products. With regard for solid consistency of these by-products, the solid state fermentation method is especially recommended for this purpose. Summarizing, white biotechnology enables, on the one hand, the utilization of the by-products from biodiesel production as substrates, which reduces the production costs of the main product, and, on the other hand, the biosynthesis of valuable products such as enzymes, pharmaceuticals, chemicals or organic acids, which makes possible to replace the conventional chemical methods of their production.

\section{LITERATURE CITED}

1. Rymowicz, W. (2006). Utilization of raw materials from biofuels production. In the expertise "Applicability of agricultural wastes in production of useful chemical substances in green chemistry and white technology processes - assessment of potential scientific research and implementation, 5-17 (in Polish).

2. Jessup, R.W. (2009). Development and status of dedicated energy crops in the United States. In vitro Cellular \& Developmental Biology - Plant 45(3), 282-290, DOI:10.1007/ s11627-009-9221-y.

3. Randelli, F. (2009). An integrated analysis of production costs and net energy balance biofuels. Regional Environmental Change 9(3), 221-229, DOI:10.1007/s10113-008-0055-7.

4. Angelidaki, I., Kongjan, P. \& Thomsen, A. (2007). Biorefinery for sustainable biofuel production from energy crops: conversion of lignocellulose to bioethanol, biohydrogen and biomethane. AD 11 Conference in Australia, 22 September.

5. Canakci, M. \& Sanli, H. (2008). Biodiesel production from various feedstocks and their effects on the fuel properties. J Ind. Microbiol Biotechnol 35(5), 431-441， DOI:10.1007/ s10295-008-0337-6.

6. Moser, B. (2009). Biodiesel production, properties, and feedstocks. In vitro Cellular \& Developmental Biology - Plant 45(3), 229-266, DOI:10.1007/s11627-009-9204-z.

7. Demirbas, A. (2007). Importance of biodiesel as transportation fuel. Energy Policy 35(9), 4661-4670, DOI:10.1016/ j.enpol.2007.04.003.

1. Markowska, J. (2007). Biomass and biofuels market in Poland. Przemyst Spożywczy 7, 19-21 (in Polish).

8. Abdelhamid, M.T., Horiuchi, T. \& Oba, S. (2004). Composting of rice straw with oilseed rape cake and poultry manure and its effects on faba bean (Vicia faba L.) growth and soil properties. Bioresource Technol. 93(2), 183-189, DOI:10.1016/j.biortech.2003.10.012.

9. Demirbas, A. (2005). Potential applications of renewable energy sources, biomass combustion problems in boiler power systems and combustion related environmental issues. Progress in Energy and Combustion Science 31(2), 171-192, DOI:10.1016/ j.pecs.2005.02.002.

10. Nielsen, C. (1995). Utilisation of straw and similar agricultural residues. Biomass and Bioenergy, 9(1-5), 315-323, DOI:10.1016/0961-9534(95)00099-2.

11. Paukszta, D. (2006). Chemical composition of the lignified part of the rape straw stem. Zeszyty Instytutu Hodowli i Aklimatyzacji Roślin w Radzikowie, Zeszyt 1, 143-150 (in Polish).

12. Van de Velde, K. \& Kiekens, P. (2001). Thermoplastic pultrusion of natural fibre reinforced composites. Composite Structures 54(2-3), 355-360, DOI:10.1016/S0263-8223(01)00110-6.
13. Kijeńska, M. (2008). Prospects for the use of economic plants wastes as thermoplastic polymer fillers. Chemik 4, 167172 (in Polish).

14. Lu, X., Zhang, Y. \& Angelidaki, I. (2009). Opimization of $\mathrm{H}_{2} \mathrm{SO}_{4}$-catalyzed hydrothermal pretreatment of rapeseed straw for bioconversion to ethanol: Focusing on pretreatment at high solids content. Bioresource Technol. 100, 30483053, DOI:10.1016/j.biortech.2009.01.008.

15. McKendry, P. (2001). Energy production from biomass (part 1): overview of biomass. Bioresource Technol. 83(1), 3746, DOI:10.1016/S0960-8524(01)00118-3.

16. Paul, D. (1986). Morphological changes of rape seed straw after sulfate pulping. Cell. Chem. Technol. 20, 429-439.

17. Papatheofanous, M.G., Koullas, D.P., Koukios, E.G., Fuglsang, H., Schade, J.R. \& Lofqvist, B. (1995). Biorefining of agricultural crops and residues: effect of pilot-plant fractionation on properties of fibrous fractions. Biomass and Bioenergy 8(6), 419-426, DOI:10.1016/0961-9534(95)00040-2.

18. Diaz, M., Cara, C., Ruiz, E. \& Romero, I. (2010). Hydrothermal pre-treatment of rapessed straw. Bioresource Technol. 101(7), 2428-2435, DOI:10.1016/j.biortech.2009.10.085.

19. Karakashev, D., Thomsen, A.B. \& Angelidaki, A. (2007). Anaerobic biotechnological approaches for production of liquid energy carriers from biomass. Biotechnol. Lett. 29(7), 10051012, DOI:10.1007/s10529-007-9360-3.

20. Ballesteros, M., Oliva, J.M. \& Negro, M.J. (2004). Ethanol from lignocellulosic materials by a saccharification and fermentation process with Kluyveromyces marxianum CECT 10875. Process Biochem. 39, 1843-1848, DOI:10.1016/ j.procbio.2003.09.011.

21. Kadar, Zs., Szengyel, Zs. \& Reczey, K. (2004). Simultaneous saccharification and fermentation (SSF) of industrial wastes for the production of ethanol. Industrial Crops and Products 20(1), 103-110, DOI:10.1016/j.indcrop.2003.12.015.

22. Karaosmanoglu, F. \& Tetik, E. (1999). Charcoal from Pyrolysis of Rapeseed Plant Straw-Stalk. Energy Sources, Part A: Recovery, Utilization, and Environmental Effect 6(21), 503510.

23. Wojtatowicz, M. (2006). Utilization of distillery effluents and other agricultural wastes. In the expertise "Applicability of agricultural wastes in production of useful chemical substances in green chemistry and white technology processes - assessment of potential scientific research and implementation", 18-26 (in Polish).

24. Witkowska, D. (1994). Protein production using enzymatic hydrolisates of rape straw. Zeszyty Naukowe Akademii Rolniczej we Wrocławiu, Technologia żywności VII (244), 199205 (in Polish).

25. Demirbas, A. (2008). Heavy metal adsorption onto agro based waste materials: A review. Journal of Hazardous Materials, 1-24, DOI:10.1016/j.jhazmat.2008.01.024.

26. Ramachandran, S., Singh, S.K., Kumar, S., Larroche, C., Kumar., Soccol, C.R. \& Pandey, A. (2007). Oil cakes and their biotechnological applications - A review. Bioresource Technol. 98(10), 2000-2009, DOI:10.1016/j.biortech.2006.08.002.

27. Antoszkiewicz, Z. (2001). Nutritional value of sunflower seed meal used for the feeding of growing pigs. Doctoral dissertation, Uniwersytet Warmińsko-Mazurski, Olsztyn (in Polish).

28. Schoene, F., Kirchheim, U., Schumann, W. \& Ludke, H. (1996). Apparent digestibility of high-fat rapeseed press cake in growing pigs and effects on feed intake, growth and weidh of thyroid and liver. Animal Feed Sci. Technol. 62(2-4), 97-110.

29. Bautista, J., Parrado, J. \& Machado, A. (1990). Composition and fractionation of sunflower meal: use of the lignocellulosic fraction as substrate in solid-state fermentation. Biol. Waste 32, 225-233, DOI:10.1016/0269-7483(90)90051-S.

30. Nilsson, L.J., Pisarek, M., Buriak, J., Oniszk-Popławska A., Bućko, P.P., Ericsson, K. \& Jaworski, Ł. (2006). Energy policy and the role of bioenergy in Poland. Energy policy 34(15), 2263-2278, DOI:10.1016/j.enpol.2005.03.011. 
31. Korytkowski, J.A. \& Inowolski, A. (2007). A complex system for biofuel production from rapeseed oil as a renewable energy source Przemyst Chem. 86 (3), 195-199 (in Polish).

32. Yorgun, S., Senzos, S. \& Kackar, O.M. (2001). Flash pyrolysis of sunflower oil cake for production of liquid fuels. Journal of Analytical and Applied Pyrolysis 60, 1-12, DOI:10.1016/ S0165-2370(00)00102-9.

33. Ucar, S. \& Ozkan, A.R. (2008). Characterization of products from pyrolysis of rapeseed oil cake. Bioresource Technol. 99(18), 8771-87, DOI:10.1016/j.biortech.2008.04.040.

34. Ohlson, R. \& Anjou, K. (1979). Rapeseed protein products. Journal of the American Oil Chemists Society 56, 431437.

35. Xu, L. \& Diosady, L.L. (2000). Interactions between canola proteins and phenolic compounds in aqueous media. Food Research International 33, 725-731, DOI:10.1016/S09639969(00)00062-4.

36. Naczk, M., Amarowicz, R., Sullivan, A. \& Shahidi, F. (1997). Current research developments on polyphenolics of rapeseed/canola: a review. Food Chemistry 62(4), 489-502, DOI:10.1016/S0308-8146(97)00198-2.

37. Thiyam, U., Kuhlmann, A., Stockmann, H. \& Schwarz, K. (2004). Prospects of rapeseed oil by-products with respect to antioxidative potential. Comptes Rendes Chimie 7(6-7), 611616, DOI:10.1016/j.crci.2004.02.011.

38. Gattinger, L.D., Duvnjak, Z. \& Khan, A.W. (1990). The use of canola meal as a substrate for xylanase production by Trichoderma reesei. Appl. Microbiol. Biotechnol. 33, 21-25.

39. El-Batal, A.I. \& Abdel Karem, H. (2001). Phytase production and phytic acid reduction in rapeseed meal by Aspergillus niger during solid state fermentation. Food Research International 34(8), 715-720, DOI:10.1016/S09639969(01)00093-X.

40. Ebune, A., Al-Asheh, S. \& Duvnjak, Z. (1995). Production of phytase during solid state fermentation by Aspergillus ficuum NRRL 3135 in canola meal. Bioresource Technol. 53(1), 7-12, DOI:10.1016/0960-8524(95)00041-C.

41. Haq, I.U., Ashraf, H., Iqbal, J. \& Qadeer, M.A. (2003). Production of alpha amylase by Bacillus licheniformis using an economical medium. Bioresource Technol., 87(1). 57-61, DOI:10.1016/S0960-8524(02)00198-0.

42. Kota, K.P. \& Sridhar, P.(1999). Solid state cultivation of Streptomyces clavuligerus for cephamycin C production. Process Biochem. 34, 325-328.

43. Sircar, A., Sridhar, P. \& Das, P.K. (1998). Optimization of solid state medium for the production of clavulanic acid by Streptomyces clavuligerus. Process Biochem 33,283-289, DOI:10.1016/S0032-9592(97)00058-7.

44. Shashirekha, M.N., Rajarathnam, S. \& Bano, Z. (2002). Enhancement of bioconversion efficiency and chemistry of the mushroom, Pleurotus sajor-caju (Berk and Br.) Sacc. produced on spent rice straw substrate, supplemented with oil seed cakes. Food Chem. 76, 27-31, DOI:10.1016/S03088146(01)00244-8.

45. Gąsiorek, E., Fronia, J., Firuta, P. \& Podgórski, W. (2007). Rapeseed meal as a substrate for biosynthesis of oxalic acid by solid state fermentation. Acta Sci.Pol.6 (3), 2732 (in Polish). 